\title{
The Crime of Genocide on the Rohingya Ethnic in Myanmar from the Perspective of International Law and Human Rights
}

\author{
Aulia Rosa Nasution* \\ DOI: https://doi.org/10.22304/pjih.v5n1.a10
}

Submitted: January 2, 2018 | Accepted: May 6, 2018

\begin{abstract}
Genocide has become one of the most essential issue nowadays in the world since the ethnic conflict on Rohingya occurred in Myanmar. This conflict which has killed thousands of innocence civilians happened over the last century and increasingly heating up in the 21st century. Genocide on the Rohingya constitute a serious international crime which was conducted widespread and systematically, carried out by state actors (state agents or military apparatus) and non- state actors by destruction in whole or in part. This research focuses on the crime of genocide that occurred in the conflict of Rohingya which reviewed based on aspects of international law and human rights. The research results show that genocide on the Rohingya Ethnic has become a crime against humanity and violates the principle of humanity.
\end{abstract}

Keywords: Genocide Convention, ethnic conflict, Rohingya.

\section{Kejahatan Genosida pada Konflik Etnis Rohingya di Myanmar Ditinjau dari Aspek Hukum Internasional dan Hak Asasi Manusia}

\begin{abstract}
Abstrak
Genosida saat ini menjadi salah satu persoalan yang paling penting di dunia sejak terjadinya insiden konflik sejak konflik etnis Rohingya terjadi di Myanmar. Konflik ini telah membunuh ribuan orang - orang sipil yang tidak bersalah yang terjadi selama berabad-abad yang lalu dan semakin memanas di abad ke-21. Genosida pada etnis Rohingya merupakan kejahatan internasional yang serius yang dilakukan secara meluas dan sistematik, dilakukan oleh aktoraktor negara (agen-agen negara atau aparat militer) dan aktor-aktor non negara dengan penghancuran secara sebagian atau keseluruhan. Penelitian ini berfokus pada kejahatan genosida yang terjadi pada konflik etnis Rohingya yang dikaji melalui aspek- aspek hukum internasional dan hak asasi manusia. Penelitian ini menunjukkan bahwa genosida pada etnis Rohingya merupakan kejahatan terhadap kemanusiaan dan melanggar prinsip-prinsip kemanusiaan.
\end{abstract}

Kata kunci: Konflik etnis, Konvensi Genosida, Rohingya.

\section{A. Introduction}

Since 2017, international community has been shocked by mass murders of hundreds, or even thousands, of Rohingyas in Myanmar. The political crisis that had taken place in Myanmar's has been started from a long time before; and extended to ethnic cleansing. Buddhist extremists are involved in the killing of thousands of

\section{PADJADJARAN Journal of Law Volume 5 Number 1 Year 2018 [ISSN 2460-1543] [e-ISSN 2442-9325]}

Lecturer at Universitas Medan Area, and guest lecturer at Army Military Law School (Sekolah Tinggi Hukum Militer) in Jakarta, nasution82auliarosa@gmail.com, S.H. (Universitas Sumatera Utara), M.H. (Universitas Muhammadiyah Surakarta), and Dr. (Universitas Jayabaya). 
Rohingya ethnic civilians. The mass killings are not viewed as murders, but only as efforts made by the Myanmar military in order to perform what they call as pest control.

These helpless Rohingya people are perceived as global Islamic agents that are spread and conspiring to take over the world and create Islamic Caliphate. On that basis, Buddhist monks and the government represented by the military regime of Myanmar move and act together to remove Rohingya ethnic, either the children, the adults, and the elders to maintain the national and religious character of Myanmar. The way that they carry out is massive and systematic killings.

Although the Myanmar government argues that their actions were carried out in order to safeguard and to protect Myanmar from Rohingya people who are perceived as "terrorists" endangering Myanmar, the actions perpetrated by Myanmar's military regime are extremely inhumane, out of humanity, and violating human rights. In addition, the Myanmar government aggressively campaigns against Rohingyas, which eventually lead to an act of genocide since the mass violence in Myanmar in 2012. The result is about 200.000-300.000 Rohingyas fleeing from Myanmar to the nearest countries such as Bangladesh and India. According to International Amnesty, since August 25, 2017, more than 750.000 refugees who are mostly women and children have left Myanmar. They crossed into Bangladesh after the Myanmar army launched numerous attacks on the Muslim minority community. The actions carried out by the Myanmar military is defined as a "cleansing effort of terrorist agents ". ${ }^{1}$ The actions carried out by the Myanmar military is defined as a "cleansing effort of terrorist agents".

These actions include killing and torturing numbers of Rohingya women, men, and children. The military which often working with Border Guard Police and local vigilantes have also conducted rape and other forms of sexual violence, laid landmines, and burned hundreds of Rohingya villages which the United Nations High Commissioner for Human Rights described it as "textbook example of ethnic cleansing". 2

The current mass murder of the Rohingyas is a tragedy of humanity. Therefore, it is very important to be resolved both diplomatically, through the ASEAN negotiating table, and through international trials. The genocide crimes on the Rohingyas should be stopped and resolved through legal means. It is expected that the Rohingyas can be saved from Myanmar's inhumane military actions. The deep concerns about the Rohingya ethnic tragedy is the background of this study. Hence, this study explains the perspectives of international laws and human rights on the crime of genocide on the Rohingya people in Myanmar.

\footnotetext{
Amnesty International, "Myanmar: Military land grab as security forces build bases on torched Rohingya villages", https://www.amnesty.org/en/latest/news/2018/03/myanmar-military-land-grab-as-security-forcesbuild-bases-on-torched-rohingya-villages/, accessed on March 2018.
}

2 Ibid. 


\section{B. Overview of Ethnic Conflict and Genocide \\ 1. Overview of Ethnic Conflict}

Before entering the discussion about the crime of genocide, an overview about ethnic conflict should be discussed. One of the factors that is considered very decisive in the crime of genocide is ethnic conflict. An ethnic conflict is usually adjacent to other conflicts that also have the potential to bring genocide like the conflicts of racial, religious, and national. ${ }^{3}$ However, the characteristics of ethnic conflict are very typical, making it as the most possible type that leads to genocide.

The concept of ethnic is essentially inseparable from the concept of nationalism. Nationalism is derived from the word 'nation', which has a meaning that is a group or people of an ethnic. In every nation, there is always a collection of people with certain unique "cultural unity" that is different from other cultural entities. These differences can be massive, such as differences in language, religion, or custom. Nevertheless, the differences may also be very small and nuanced, but still form different sets. A group of people with a particular cultural unity is called ethnic unity. ${ }^{4}$

More fundamentally, ethnicity can be defined as a community of people with a name. It can be related to one country, have a common noble myth, have shared memories. It covers one or several common cultural elements and solidarity. It can be said that one nation is rarely composed of only one ethnic group. Mostly, the countries of the world consist of ethnicities.

After the end of the Cold War and the subsequent dissolution of the Soviet Union, many people hoped that times of peace would fill the world. A secure and prosperous new world order, which would prevent the breaking up of nations, had become the dream of the past rulers. Nevertheless, this expectation is not a reality because, after the Cold War, the world had seen many ethnic conflicts in the middle of diverse economic and political interests.

According to Michael E. Brown, ethnic conflict is a conflict related to the urgent issues of politics, economy, social, culture, and territoriality between two ethnic communities or more. ${ }^{5}$ The definition indicates the existence of two elements in an ethnic conflict-substantial and subject elements. A substantial element refers to the "content" of ethnic conflicts: political, economic, social, cultural, or territorial disputes. A subject element is the characteristic of ethnic conflict, referring to the parties involved in the ethnic conflicts-for example two or more ethnic communities. Ethnic community can be defined as a human population united by same ancestor, memories of same events, and cultural elements, land or country, and effort of solidarity. ${ }^{6}$

Arie Siswanto, Hukum Pidana Internasional, Yogyakarta: Andi Offset, 2015, p. 52.

4 Budi Winarno, Dinamika Isu-Isu Global Kontemporer, Yogyakarta: Center of Publishing Academic Service, p. 247.

5 Michael E Brown, "Causes and Implications of Ethnic Conflict", in Monsterrat Guibernau and John Rex, The Ethniciy Reader, Nationalism, Multiculturalism and Migration, Cambridge: Polity Press, 1997, p. 82.

$6 \quad$ Ibid. 
Brown further explains that an ethnic community must meet six criteria. First, the community must have its own name as a collective identity. Second, the members have the conviction that they have experience of same ancestor. Third, the members feel that they share a same history. Fourth, the community has a same culture. Fifth, the community feels that they are connected to a particular area. Sixth, the last, the members should regard themselves as a group, a self-awareness. ${ }^{7}$

When it comes to ethnic conflict, it is commonly understood that the conflict is merely because of inter-ethnic hatred, especially the hatred that has taken place for generations. However, ethnic hatred is not a sole problem that necessarily leads to ethnic conflict. For example, in Europe, Czech versus Slovak and Ukraine versus Russia have a long history of ethnic contests. However, these conditions will not necessarily lead to the outbreak of serious ethnic conflict. Therefore, while hate factors often play an important role in ethnic conflict, it is more appropriate to understand that it is only one of many factors causing ethnic conflicts that can lead to genocide. ${ }^{8}$

An ethnic conflict usually leads to violent. Ethnic conflicts that were occurred in Rwanda, Bosnia, and Angola have tremendous dimensions of violence. Thematically, Brown identifies four clusters of factors that can create ethnic conflict. They are, among others (1) structural factors caused by weak state and domestic security issues; (2) economic and social factors, namely the allocation of unfair economic resources; (3) political factors, like discriminatory political system; and (4) cultural factors and persistence in the form of hatred for generations. ${ }^{9}$

Clearly, an ethnic conflict is caused by several factors. The first factor is the emergence of ethnocentrism. The concept of ethnocentrism is often used together with racism. This concept represents an understanding that every ethnic or racial group has the spirit that their own group is superior, compared to other groups, so that other ethnic groups are inferior to their own. The clearest example is Adolf Hitler who considers the Jews to be the lowest in the world and deserve to be annihilated.

The second factor is territorial legitimacy. Especially for the 'immigrant' ethnic group who inhabit other areas of the nation. The 'indigenous' ethnic group can carry out a cleaning operation (Ethnic Cleansing) for the 'immigrant' ethnic group because they want their nation's territory to be inhabited by only the original descendants of the nation. For example, Hungarian people in Romania, Tamil in Sri Lanka, and white people in South Africa experience it.

The third factor is the existence of negative stereotypes that appear to a particular ethnic inherited from generation to generation so that the image or the look of the ethnic is always bad. For example, in the case of ethnic conflict between Chinese and indigenous in Tangerang, Indonesia, the Chinese regard the indigenous as lazy, ignorant, unable to use good opportunities and so on. On the other hand, 
the Chinese descent is called as a group who want their own profit without thinking about people interest.

The fourth factor is discrimination against certain ethnic groups that lead to prejudices of injustice such as discrimination in government, organizations, education, and so forth. This usually occurs in ethnic minorities within a region. Fifthly, there are threats arising from other ethnic groups that trigger conflict, such as seizure of territory, violence, and others.

The sixth factor is the existence of social gap that occurs among ethnics. It is especially in a nation that has many ethnic groups. Certain differences, such as religion, culture, language, and others can cause the social disparity. The sixth factor is provocation of another party (usually from political actors) who want to take advantage of the conflict by contesting two or more ethnic groups to fight. The seventh factor is the presence of threats arising from other ethnic groups that trigger conflict. The eighth factor is that many countries do not yet have adequate laws to protect the rights of minority ethnic groups. Even countries that have established legal provisions (enforcement) formally also still experience many obstacles and constraints in preventing conflict.

\section{Ethnic Conflict in Myanmar}

Rohingya is a minority Muslim ethnic group in Myanmar. They predominantly live in the state of Arakan (Rakhine). Initially, the Rohingyas were immigrants from the Middle East who settled in Arakan because of the coming of Arab traders to the region of Southeast Asia. At the time, Arakan was not a territory of Myanmar, but was an area that had not yet registered in any administration. However, in 1785, Myanmar started to control it so that the Rohingyas were under the administration of Myanmar.

Although Arakan is within the territory of Myanmar, and is under the rule of Myanmar, the Rohingyas are not recognized as Myanmar nationals. This has led to continuous repression and discriminative acts against Rohingyas from other nonMuslim ethnic groups in Arakan. Rohingya ethnic residents, before the conflict that seized much of the world's attention in 2012, have often experienced acts of violence from both the government of Myanmar and from other ethnics that are mostly Buddhist. In addition to acts of violence, Rohingyas also suffered administrative difficulties because they were not recognized as citizens of any country.

In Myanmar, the Rohingyas have difficulty to get married and to build family. The Myanmar government requires Rohingyas to seize government permits before they get married. Nevertheless, to get the permit, they have to wait very long and pay very expensive cost. In addition, they must also agree with the government that they will not have more than two children. Such restrictions are in fact a form of ethnic cleansing and genocide that are criticized by international community. ${ }^{10}$

$10 \quad$ lbid. 
Rohingyas are also inhibited to gain access to natural resources and property rights. Arakan is a relatively poor region of Myanmar and the Rohingyas must be under other ethnics because they are not considered as citizens and are not under government protection. From the social and economic perspectives, the life of Rohingyas is very poor, suffering, and discriminated, not to mention physical violence and murders for many years. All forms of oppression and discrimination are resulted from the non-recognition of Rohingyas as a part of Myanmar. With their 'Stateless' status, they have become more vulnerable and have no defense and protection of human rights. ${ }^{11}$

The conflict in Myanmar against Rohingya ethnic people have been going on for decades. The conflict has been escalating massively to the top in early 2012 . The Rohingya ethnic conflict stems from the tragedy of rape and the murder of a Buddhist girl by three Rohingyas on May 28, 2012. The locals did not accept and demanded revenge to the Rohingyas. The incident eventually sparked the conflict between Rohingya ethnic communities and other local communities. The result is that the Rohingyas is targeted by the masses of other ethnics. The Rohingyas do not only face violence but also the destruction of citizens' possessions and other violence such as murder, forcible transfer, rape, oppression, persecution, and other inhumane acts. This causes most of the Rohingyas to flee to other countries such as Thailand, Indonesia, Bangladesh, and India.

At least two main factors make Rohingya ethnic conflict attracting the world attention. ${ }^{12}$ First, the conflict is potentially growing toward genocide. Genocide has been categorized as an international crime as set out in the Convention on the Prevention and Punishment of the Crime of Genocide 1948 (Genocide Convention of 1948)..$^{13}$ Genocide has also been categorized as a crime against humanity as provided in Article 5 of the Rome Statute of the International Criminal Court 1998 (Rome Statute).${ }^{14}$ Genocide is a serious international crime that cannot be separated from the past where Hitler tried to exterminate Jewish ethnic groups in Europe during the reign of Nazi German military regime that resulted into the deaths of 6.5 million Jews. Second, the involvement of state or community groups in other countries. Although ethnic conflicts are almost local in nature, in its development, however, it often invites community groups in other countries. In fact, other countries often get involved in the "local war". 15

For example, the conflict between Hutu and Tutsi in Rwanda. The two ethnics killed each other because of differences in ethnicity and party. In addition, there was also conflict of interest involving some parties in the country. ${ }^{16}$ The ethnic conflict in Rwanda resulted in the mass killings of the Tutsi ethnic. The bodies of Tutsi people

Ibid.

Budi Winarno, Op.cit., p. 257.

See Article II of the Convention on the Prevention and Punishment of the Crime of Genocide, adopted by United Nations General Assembly Resolution 1948 (Genocide Convention of 1948).

14 See Article 5 of the Rome Statute of The International Criminal Court 1998 (Rome Statute).

15 Budi Winarno, Loc.cit.

16 Budi Winarno, Op.cit., p. 252. 
were thrown into rivers. The conflict that occurred in 1994 is known as the Rwandan Genocide. The killings were a genocidal mass slaughter of approximately 800,000 Tutsi in Rwanda by a group of Hutu extremists known as 'Interhamwe'. The conflict occurred within the 100-day period in 1994.

Another example is religious-related ethnic conflict such as those that occurred in Bosnia during the Bosnian war. The ethnic conflict in Bosnia dated from the breakup of the Yugoslavia state, which resulted in the state breaking into several states. The ethnic conflict in the Balkan region occurred in 1992-1995. Prior to the conflict, much earlier, the area had been divided into the ethnicity perpetuated by President Joseph Tito of Yugoslavia. Then, when Yugoslavia broke up, ethnic divisions became increasingly inevitable and led to a terrible ethnic war. ${ }^{17}$

In the former Yugoslavia, there are three major ethnics: Serbian, Croatian, and Bosnian. The dissolution of Yugoslavia began with the release of Croatia and Slovenia in June 1991. Later that year, the parliament of Bosnia and Herzegovina voted for independence. The result of the vote is that they want to form an independent state apart from Serbia. This sparked opposition and ethnic divisions, resulting in an inter-ethnic war that began when Serbia bombarded the capital of Bosnia, Sarajevo, and other cities. Murders were committed across the country and killed hundred thousand of Bosnians, most of whom were Muslim.

The peak of the humanitarian tragedy occurred in 1995 in Srebrenica region, when Serbian soldiers killed more than 8,000 Bosnians. The event is known as the "Srebrenica Tragedy". During the Bosnian war, that occurred in the period 19921995 , no less than two million people displaced. It attracted international attention. Bosnian Muslim massacres by Serbian have encouraged Muslim sentiment around the world.

The third factor is the implications of ethnic conflict at the regional level. A local conflict will be of global concern if the conflict leads to the destabilization of the region. Usually it happens when the conflict involves actors outside the country where the ethnic conflict occurs. If this happens, ethnic conflict will invite the world's attention and ultimately lead to destabilization of the surrounding area. It will certainly lead to a huge wave of refugees like in Rwanda and Bosnia. ${ }^{18}$

The term "ethnic cleansing" is used initially to refer the war in the former Yugoslavia. It is referred to actions taken by Serbian military forces in Bosnia and Herzegovina that displaced Muslims and Croats out of their neighborhoods. The act of forced displacement was aimed at creating an area occupied solely by Serbs, who would later unite to form the "Great Serb". Such actions were carried out by means of "cleansing operations", in which civilians were massacred and abused, sexually abused, cities were bombed, places of worship were destroyed, and houses of residence were confiscated. The term "ethnic cleansing" describes a complex crime phenomenon. The application of the ethnic cleansing policy is accompanied

Budi Winarno, Op.cit., p. 251.

18 Budi Winarno, Op.cit., p. 258. 
by serious human rights violations directed at forcing an ethnic group out of a particular territory in order to alter the ethnic composition of a population. ${ }^{19}$

\section{Defining Genocide}

The term genocide consists of two words namely 'geno' and 'cide'. Geno, or genos, is derived from ancient Greek. It means race, nation, or ethnicity. The word cide, caedere, or cidium is derived from Latin, means to kill. ${ }^{20}$ Literally, genocide can be interpreted as 'ethnic murder' or 'racial murder'. The term was introduced by Raphael Lemkin in 1944. Lemkin is a Polish-born Jew who migrated to America in 1930. Lemkin, the inventor of the term genocide briefly defines of genocide as "the destruction of a nation or an ethnic group."

Lemkin describes that genocide should not always be understood as the act of destroying a nation directly but more importantly is that genocide is intended to paralyze foundations of life of a particular national group with the ultimate goal of the annihilation of the nationalist group. ${ }^{21}$ Lemkin also puts forward an important characteristic of genocide, which then influences the legal definition of genocide within the instruments of international conventions. Lemkin says that genocide is directed against a particular national group as an entity, and the action is directed against individuals, not their capacity as individuals, but as members of a national group. ${ }^{22}$

According to Lemkin, genocide can be defined completely as a coordinated and organized plan of various actions that are aimed at destroying the foundations in the life of a particular nation or group to eliminate the nation or the group. The objectives of the plan are the disintegration of political and social institutions of culture, language, nationalism, religion, economic existence of certain groups and the destruction of personal security, liberty, health, degrees and even the lives of people that belong to the group. ${ }^{23}$

Further, according to Lemkin, the action of Genocide is divided into two phases. The first phase is to destroy the pattern of nationality of the oppressed group. The second phase is to obstruct nationality of the oppressed group. ${ }^{24}$ This obstruction can be done to the remaining oppressed populations, or over territory, after the oppressive group removes the oppressed group population and occupies the area with the members of the oppressor group.

The term 'genocide' is started to be used widely when the United States filed lawsuits against German Nazi war criminals to the International Military Tribunal (IMT) in Nuremberg, Germany. ${ }^{25}$ Although the term genocide is only emerged in the early 1940s but the prosecution effort against genocide crime had been started

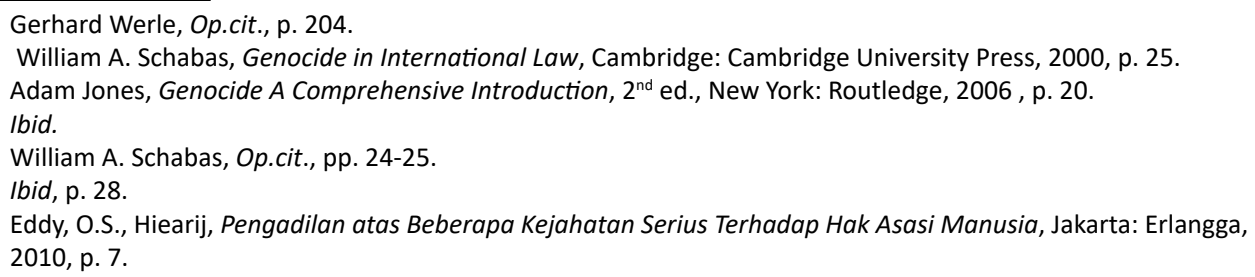


since 1918. It was at the meeting of 'Imperial War Cabinet', on November 20, 1918, Lord Curzon of England emphasized the prosecution of the leader of Germany and the Young Turk leaders who purge the minority Armenia ethnic in Turkey. It was just that objectively the prosecution did not use the term 'genocide' but with the term 'atrocious offences against the laws of war'. Therefore, it is very precise what sociologist Leo Kuper suggests that although genocide is a new term, it is actually an old concept. ${ }^{26}$

Although modern studies of genocide started to develop by Lemkin's activities in the early $20^{\text {th }}$ Century (defined as a practice of mass killings against a group of people for reasons of race, ethnic, religious, or nationality), it is as old as the history of human civilization. According to Chalk and Jonassohn, genocide behavior is closely related to human history because, essentially, anthropologically, and historically a community usually has a category for themselves. They will give different predicates to other groups of people. When other groups are perceived as very different and inferior in terms of behavior, beliefs, customs and traditions, they usually are given predicates that reflect inhumanity such as 'barbarians', 'infidels', or other terms that refers to animals. ${ }^{27}$

The factor of inhumanities (considering other groups of people as lower creatures) in the history of genocide proves to be one of the important elements contributing to the genocide. One of the dehumanization processes leading up to genocide can be seen in the Nazi propaganda of Germany. In tabloid propaganda Der Sturmer, the Jews are called 'parasites', 'grasshoppers', and 'our misfortune'. The strong smell of dehumanization is also present in various cases of genocide, including in the Rwandan genocide incident involving Hutu and Tutsi. In that event, the Hutu tribe dehumanized the Tutsi tribe as victims of genocide by calling them 'cockroaches'. ${ }^{28}$

Bryan A. Garner in the Black's Law Dictionary defines genocide as an act intended to destroy, in whole or in part, a nation, an ethnic, a racial or religious group..$^{29}$ Goldstein defines genocide as "systematic extermination of an ethnic, a race, or a religious group". ${ }^{30}$ From the definitions, it is clear that genocide contains two elements. First, it is the act of killing or destruction; and second, the target is a particular group.

The action or performance that can be punished as a crime of genocide is if the action or performance is intended to destroy a particular nation, ethnic, race, or denominational group in whole or in part. The physical and psychological condition of the targeted group becomes the main protection. The dignity of genocide victims is also protected. The crime of genocide requires the actions set forth in Article 6(a)

Adam Jones, Op.cit., p. 3.

Arie Siswanto, Op.cit., p. 31.

Ibid.

Bryan A. Garner, p. 694.

Arie Siswanto, Yurisdiksi Material: Mahkamah Kejahatan Internasional, Bogor: Ghalia Indonesia, 2005, p. 48. 
to (e) of the Rome Statute. The targets of genocide are individuals who are part of a particular group.

The material elements of genocide do not require that individual action is part of a widespread or systematic attack against a particular group. Meanwhile the mental element of genocide requires that material element of the crime is committed by 'intent and knowledge' as set forth in Article 30 of the Rome Statute.

In addition, genocide requires the existence of a specific intention to destroy a nation, an ethnic, a race, or a religious group in whole or in part. Therefore, the purpose of the genocidal actors is to destroy a group, in whole or in part, is not a major element. The intention to destroy simultaneously is a systematic element of a crime of genocide, causing it to become an international crime. ${ }^{31}$

The destruction of a particular group can also be manifested by destroying the group's identities such as physical annihilation, which leads to the group's death and loss to human civilization. The destruction of a group becomes a danger to individual rights of a particular group that causes it to become an international crime of genocide. ${ }^{32}$ The group here is defined as a group with characters of 'national', 'ethnic', 'race', or 'religious' that are protected in the definition of the crime of genocide.

The term group should fulfilled several criteria. First, the group has similarities in customs, language, religion, or nature of properties that look the same as skin color or stature. However, the group can also be seen from subjective and other perspectives. Second, the group is a national group that is formed because it has similarities in terms of history, customs, culture, and language. Third, the group is an ethnic group that share same or identical characters of a nation, a race, or a religion. Ethnic groups can be distinguished specifically by specific cultural traditions and same history. Members of a particular ethnic group speak a same language, have same customs and habits, and share same way of life. Ethnic group can be found within a particular geographical region or region. Fourth, the group is a particular racial group. The racial group here refers to a social group whose members inherit same physical properties like skin color or physical stature. Fifth, the group is a particular religious group. Religious group is described in United Nations General Assembly Resolution 96 (I) of 1946. It is a group that can be victims of crime genocide and also can be vanished as a result of crime genocide. Members of religious group share same beliefs, spiritual paradigm, spiritual thoughts, or religious practices. It can be a small group, a religious sect, and huge group of a particular religion. ${ }^{33}$

Furthermore, crime of genocide targets individuals in a particular group. The Rome Statute describes the types of genocide as the acts of killing; ${ }^{34}$ acts that cause

Gerhard Werle, Op.cit., p. 192.

Gerhard Werle, Op.cit., p. 193.

Gerhard Werle, Op.cit., pp. 195-199.

Article 6(a) of the Rome Statute. 
serious body or psychical injuries; ${ }^{35}$ acts that cause devastating mental condition conditions; ${ }^{36}$ acts to prevent births within a group can also be regarded as a form of biological genocide; ${ }^{37}$ and in addition, acts that represent forcible transfer of children from one group to another group represents a special form of genocide..$^{38}$

\section{International Legal Instruments on Genocide}

1. "Genocide" in the Statute of the International Military Tribunal of Nuremberg, Germany

Although the term 'genocide' cannot be found in the Charter of the International Military Tribunal of Nuremberg 1945 (Nuremberg Charter), the substance of genocide regulation has actually been contained in the Nuremberg Charter. It is clearly stated as follows: ${ }^{39}$

"Crimes Against Humanity: namely murder, extermination, enslavement, deportation and other inhumane acts committed against any civilian population, before or during the war, or persecutions, on political, racial or religious grounds in execution of or in the connection with any crime within the jurisdiction of the Tribunal, whether or not in violation of the domestic law of the country where perpetrated".

In that definition, the mention of 'persecutions on ... racial or religious grounds ...' then evolved into one specific form of 'crime against humanity' which was later investigated under the name of genocide. In fact, the term 'genocide' does not have to wait long to appear in the judicial process based on the Nuremberg Charter. When prosecuting the commander of Einsatzgruppen forces who committed mass crimes in Poland and Russia during World War II, the prosecutor used the term 'genocide' to describe their actions..$^{40}$ It can be said that according to the Nuremberg Charter, materially, crime of genocide is still integrated in crimes against humanity. The formulation of genocide as a separate category of crime apart from crimes against humanity is realized explicitly after the Genocide Convention of 1948.

\section{2. "Genocide" in the Genocide Convention of 1948}

The Genocide Convention of 1948 is a comprehensive document on genocide that has been signed by countries. The Genocide Convention of 1948 has such an important role in view of the various legal instruments underlying the establishment of various ad hoc judiciaries in the future. The term 'genocide' was formally described in the Genocide Convention of $1948 .{ }^{41}$ The Genocide Convention of 1948 was a reaction to the genocidal action perpetrated by German Nazi soldiers. Similarly, the world was

Article 6(b) of the Rome Statute.

Article 6(c) of the Rome Statute.

Article 6(d) of the Rome Statute.

Gerhard Werle, Op.cit., p. 199. See also Article 6(e) of the Rome Statute.

Article 6(c) of the Charter of the International Military Tribunal of Nuremberg 1945.

John Quigley, The Genocide Convention: An International Law Analysis, Hampshire: Ashgate Publishing Limited, 2006, p. 6.

41 See the Genocide Convention of 1948. 
struck by the tragedy in Nigeria after a wave of mass killings by the Ibo group in the western part of the country where the population is predominantly an Ibo ethnic group seeking independence. In July 1967, a war broke out in eastern region of Nigeria between the government and Ibo ethnic group. The Ibo ethnic group became the target of an extermination campaign that caused about 600,000 to millions of Ibo people lost their lives. Many Ibo people were massacred or died because of the famine that was caused by the war. ${ }^{42}$

Until the end of the $20^{\text {th }}$ century, atrocities in Rwanda and in some areas of the former Yugoslavia became the international concern. In Rwanda, a civil war broke out in April 1994 after the Prime Minister of Rwanda was killed in an airplane crash. In the following month, the Hutu ethnic group tried to wipe out the Tutsi ethnic, led by the military and militia groups. Because of the ethnic war, within a few months, 500.000 to 1.000 .000 civilians died. ${ }^{43}$

Genocide crimes were also committed during ethnic and religious wars in Bosnia, as declared by the International Criminal Tribunal for the Former Yugoslavia (ICTY). In July 1995, a number of Bosnian Serb soldiers took over the enclave of Srebrenica, which has actually been declared a safe area by the United Nations. It was a place where a number of Muslims seek refuge from the ongoing war. The Bosnian Muslims were separated. The women, the children, and the elderly people were forcibly relocated while the men were killed. ${ }^{44}$

According to Article 1 of the Genocide Convention of 1948, crime of genocide committed at peace or at war are crimes under international law. ${ }^{45}$ States are obliged to prevent and to punish the perpetrators. Article 2 of the convention contains a complete definition of genocide that genocide is any of the following acts committed with the aim of spoiling, in whole or in part, a national, an ethnic, or a religious group. It includes (1) killing members of the group; (2) causing bodily or mental injuries to group members; (3) intentionally inflicts physical damage in whole or in part; (4) impose measures intended to prevent births within a group; and (5) transferring children of a group to another group by force. ${ }^{46}$

Meanwhile, Article 3 of the Genocide Convention states that the acts which may be punishable include (1) genocide, (2) conspiracy to commit genocide, (3) incitement directly and publicly to commit genocide, (4) attempt to commit genocide, and (5) involvement in genocide. In other words, evil conspiracy, experiment, and participation to commit genocide can be punished like performing genocide itself. ${ }^{47}$

Article 4 of the Convention makes it clear that persons committing genocide or any actions referred to in Article 3 of the Convention may be punished, whether

\footnotetext{
Gerhard Werle, Op.cit., p. 189.

Ibid.

Ibid.

Article 1 of the Genocide Convention of 1948.

Article 2 of the Genocide Convention of 1948.

Article 3 of the Genocide Convention of 1948.
} 
they are legal rulers, public officials, or individuals. ${ }^{48}$ The Article 4 indirectly contains the principle of individual criminal responsibility. It is a principle that requires the perpetrators of international crimes to bear their own criminal responsibility as an individual, regardless of the status or the position in government. In other words, principal status, like a public official or even a ruler, cannot be used as an excuse or self-protection to avoid individual criminal responsibility. This principle can also be found in the Charter of the International Military Court of Nuremberg, Germany.

Article 5 of the convention explains that the Genocide Convention of 1948 is a convention that the implementation is highly dependent on the states. To that end, Article 5 of the Convention requires that member States of the Convention to adopt national legislation to ensure the implementation of the provisions of the Convention to the national scope, in particular to provide criminal penalties for perpetrators of genocide. ${ }^{49}$

Article 6 of the convention affirms that courts that have jurisdiction to prosecute perpetrators of genocide are the competent courts of the country in which the genocide takes place. However, the Convention also opens opportunities for international courts to exercise their jurisdiction based on the consent of the member States of the Convention. ${ }^{50}$

Article 7 of the convention contains provisions stating that genocide is not categorized as a political crime, especially in the context of extradition. This affirmation is important, because in the international law concerning extradition, there is a principle of non-extradition of political offenders. Based on this principle, when a political offender in a country escapes to another country, he/she should be protected in the country in which he/she is located. In connection with this, the assertion that genocide is not a political offense is of course intended to prevent a state giving asylum to a genocidal criminal. The criminal must be left to a state that wants to apply jurisdiction to prosecute and punish the criminal. This idea is in line with the principle of the International Criminal Code, which is known as the principle of 'Aut dedere aut punere' -meaning that the perpetrator of international crime is punished according to the place where he committed the crime. In other words, an international criminal is tried based on locus delicti.

\section{3. "Genocide" in the Statute of International Criminal Tribunal for the Former Yugoslavia}

The term genocide has also been formulated in the Statute of the International Criminal Tribunal for the former Yugoslavia which was adopted by United Nations Security Council Resolution 827 on May 25, 1993 (ICTY Statute). The ICTY Statute covers a number of crimes, including genocide. It defines genocide as any of the acts committed with the intent to destroy, in whole or in part, a nation, a race, or a

\footnotetext{
Article 4 of the Genocide Convention of 1948.

49 Article 5 of the Genocide Convention of 1948.

50 Article 6 of the Genocide Convention of 1948.
} 
particular religious group. The acts include (1) killing members of a particular group; (2) causing bodily or mental injuries to group members; (3) intentionally inflicts physical damage in whole or in part; (4) impose measures intended to prevent births within a group; and (5) transferring children of a group to another group by force. ${ }^{51}$ The elements of genocide in ICTY Statute are as follows: 52

1. Genocide can be actions of: (1) killing members of a particular group; (2) causing bodily or mental injuries to group members; (3) intentionally inflicts physical damage in whole or in part; (4) impose measures intended to prevent births within a group; and (5) transferring children of a group to another group by force.

2. Genocide is committed with the intention of destroying a national, an ethnic, a race, or a religious group, whether in whole or in part. The targets of genocide are a nation, an ethnic, a race, or a religious group.

\section{4. "Genocide" in the Statute of the International Criminal Tribunal for Rwanda}

Almost the same as the ICTY Statute, the Statute of the International Criminal Tribunal for the Prosecution of Persons Responsible for Genocide and Other Serious Violations of International Humanitarian Law Committed in the Territory of Rwanda and Rwandan Citizens Responsible for Genocide and Other such Violations Committed in the Territory of Neighboring States, between January 1, 1994 and December 31, 1994, adopted by United Nations Security Council Resolutions 955, 1994 (ICTR Statute) is the statute of an ad hoc International Criminal Tribunal for Rwanda (ICTR) established specifically to deal with serious human rights violations as well as international crimes committed in Rwanda as response to ethnic clashes between Hutu and Tutsi that claimed the lives of 500,000 to 1,000,000 civilians. The ICTR also regulates the same elements of genocide as the ICTY. Article 2(2) of the ICTR Statute states that:

"Genocide is any of the following acts committed with intent to destroy as a whole or in part, a nation, an ethnic, a race, or a religious group: (a) killing members of a particular group; (b) causing serious injury or life-threatening harm to members of a particular group; (c) deliberately inflicting conditions on a particular group which may lead to total or partial destruction; (d) taking intended measures to prevent birth within a particular group; and (e) forcibly transferring children from one particular group to another". ${ }^{53}$

\footnotetext{
Article 4 of the Statute of the International Criminal Tribunal for the former Yugoslavia, adopted by United Nations Security Council Resolution 827, 1993 (ICTY Statute).

52 Arie Siswanto, Op.cit., p. 59.

53 See Article 2(2) of the Statute of the International Criminal Tribunal for the Prosecution of Persons Responsible for Genocide and Other Serious Violations of International Humanitarian Law Committed in the Territory of Rwanda and Rwandan Citizens Responsible for Genocide and Other such Violations Committed in the Territory of Neighboring States, between January 1, 1994 and December 31, 1994, adopted by United Nations Security Council Resolutions 955, 1994 (ICTR Statute).
} 


\section{Regulation on Genocide in the Rome Statute}

Similar to the Statute of ICTY and ICTR, the Rome Statute underlying the establishment of the International Criminal Court (ICC) also adopts the definition of genocide contained in the Genocide Convention of 1948. Based on the international instruments, it is clear that the term genocide refers to a definition that show some elements as follows: ${ }^{54}$

1. The first element covers positive or negative actions. The positive action is called crime by commission, while the negative action is called crime by omission. The actions herein include 'killing members of a group'. It means the action must result in death of a member of a nation, an ethnic, a race, or a religious group.

2. The second element includes 'causing physical or mental injuries to a group'. This act is a material offense. This means that the action may cause an impact of both physical and mental injuries of a group of nation, race, ethnics, or religion.

3. The third element mentions 'intentionally inflicts physical damage on a group living conditions that are thought to cause physical damage in whole or in part'. This act also explicitly mentions deliberate intentionality as a form of error and is a material offense that focuses on physical damage of a nation, a race, an ethnic, or a religious group.

4. The fourth element states the actions of 'taking intended measures to prevent birth within a particular group'. This act is a form of mistake in the form of deliberate intention to prevent birth in a group of nation, race, ethnic, or religion

5. The fifth element, which is the last element of the crime of genocide, stipulates 'forcibly transferring children from one particular group to another'. This act may be a form of : (1) coercion to make transfer of children from one national group to another national group; (2) from one national group to another race group; (3) from one national group to another ethnic group; (4) from one national group to another religious group; (5) from one racial group to another racial group; (6) from one racial group to another racial group; (7) from one racial group to another religious group; (8) from one ethnic group to another ethnic group; (9) from one ethnic group to another religious group; and (10) from one religious group to another religious group.

\section{E. Ethnic Conflicts and Genocide Causes}

It is clear that according to the Genocide Convention of 1948, groups that may be the target of genocide include racial, religious, national, and ethnic groups. However, it is well known that there is a tendency to assume that, presently, ethnic groups have a greater chance of being target of genocide crimes. It is also common that ethnic group categories also cover same religious identity (so that an ethnic group can also be regarded as a religious group). Sometimes, an ethnic group also have same national idea (so that an ethnic group can also be considered as a national group). ${ }^{55}$

$54 \quad$ Eddy O.S., Hiarij, Op.cit., p. 14.

55 Arie Siswanto, Op.cit., p. 50. 
Considering that the crime of genocide is an act directed against certain group of ethnic (or religious, national, and racial). An ethnic conflict can be defined as the background of a genocide. In this regard, Michael E. Brown defines ethnic conflict as a dispute of political, economic, social, cultural, or territory between two or more ethnic communities. Thus, ethnic conflict is a conflict involving two or more ethnic communities. ${ }^{56}$

Furthermore, Brown also says that there are six criteria for a group to be categorized as an ethnic community. First, the group has its own name as a reflection of identity. Second, the members of the group believe that they have a same ancestor. Third, the members of the group feel that they have the same historical experience. Fourth, the members of the group have a same culture. Fifth, the group must be related to a particular area. Sixth, the members of the group should consider themselves as a group. ${ }^{57}$

\section{E. Genocide as a Serious Violation of Human Rights}

At the international law level, examined, the crime of genocide from the elements of the act and its effects can be classified as one type or a part of serious international crimes. The serious types of international crimes include: (1) war crimes; (2) genocide; (3) crime against humanity; and (4) torture.

Article 6 of the Rome Statute clearly states that genocide means any of the following acts committed with: (a) the intention to destroy, in whole or in part, a nation, an ethnic, a race, or a religious group; (b) killing members of a particular group; (c) causing serious injury or life-threatening to members of a particular group; (d) deliberately inflicting living conditions of a particular group that are expected or predicted to cause overall or partial destructions; (e) taking intended measures to prevent birth within a particular group; and (f) forcibly transferring children from one particular group to another. ${ }^{58}$

The crime of genocide is essentially a form of serious international crimes as set out in the the Rome Statute where the ICC has jurisdiction to try. In addition, the crime of genocide is also a 'jus cogens', a compelling norm or law that must be obeyed and followed by states of the world because it is in the highest hierarchical position compared to all other norms and principles. The norm of jus cogens is considered peremptory and cannot be ignored. Against this crime, every human being has a responsibility (obligatio erga omnes) to do punishment fairly.

Genocide is a violation of human rights. Based on Article 2 of the Universal Declaration of Human Rights 1948 (UDHR), it states that: ${ }^{59}$

"Everyone is entitled to all the rights and freedoms set forth in this Declaration, without distinction of any kind, such as race, color, sex,

\footnotetext{
Michael E. Brown, Ethnic and Internal Conflicts: Causes and Implication (Nationalism and Ethnic Conflict), Princeton: Princeton University Press, 2001, p. 5.

Michael E. Brown, Op.cit., p. 3.

See Article 6 of the Rome Statute.

See Article 2 of the Universal Declaration of Human Rights 1948 (UDHR).
} 
language, religion, political or other opinion, national or social origin, property, birth or other status. Furthermore, no distinction shall be made on the basis of the political, jurisdictional or international status of the country or territory to which a person belongs, whether it be independent, trust, non-self-governing or under any other limitation of sovereignty".

The UDHR defines every individual is without distinction of any kind, such as race, color, sex, language, religion, political or other opinion, national or social origin, property, birth or other status. Furthermore, no distinction shall be made on the basis of the political, jurisdictional or international status of the country or territory to which a person belongs, whether it be independent, trust, non-self-governing. This is, of course, very contradictory to the Rohingya ethnic genocide in Myanmar, where most of the Rohingya Muslims are annihilated by the Military of Myanmar through acts of genocide, extermination, enforced disappearance, and even mass killings, which are clearly contrary to the principles and recognition of human rights stipulated in the Article 2.

The crime of genocide is also contained in Law Number 26 of 2000 on the Indonesian Court of Human Rights (Indonesian Human Right Courts Law). In Article 8 of the Indonesian Human Right Courts Law, genocide is defined as any acts done with the intention to destroy or abolish all or a part of a group of nation, race, ethnic, religious by (a) killing the group members; (b) causing severe physical or mental harm to the group members; (c) creating living conditions of the group that will result in physical destruction in whole or in part; (d) imposing measures of actions aimed at preventing birth within the group; and (e) forcibly transferring children from a particular group to another group.

From this formula there are two elements in the crime of genocide. First, the common elements of the crime of genocide are in the form of mental elements and criminal elements in the crime of genocide, or the material element.

\section{General Elements on Crime of Genocide}

The Indonesian Human Right Courts Law regulates some common elements or parts that constitute a crime of genocide. They are (a) homicide (killing members of a group); (b) causing serious or mental harm; (c) deliberately inflicting certain conditions of lie on the target group; d) taking measure to prevent birth within a group; and (e) forcibly transferring children of a target group form. ${ }^{60}$ The general elements of the genocide can be described as follows:

\section{a. Intention and Consciousness}

The mental element of the action of genocide is the existence of 'intention and consciousness' as set forth in Article 30 of the Rome Statute. It is a special intention to destroy a protected group in whole or in part. ${ }^{61}$ The first subjective requirement

\footnotetext{
Mahrus Ali and Syarif Nurhidayat, Penyelesaian Pelanggaran HAM Berat: In Court System \& Out Court System, Depok: Gramata Publishing, 2011, p. 23.

61 Gerhard Werle, Op.cit., p. 206.
} 
of this mental element is that perpetrator commits genocide actions with intention and awareness. The acts of killing committed as part of attacks directed against civilian populations under conditions of armed conflict are also included here. The phrase 'with purpose' is a mental element (mens rea) or, in another language, an 'intention'. In other words, there must be intention of perpetrator to do the act. Intention can be special, specific, dolus specialis, particular, and intention to do a genocide. ${ }^{62}$

Intention must also be distinguished from motive. Specific intention is different with motive. Personal motive, for example, are to possess private economic gain or political gain or power, but the existence of a personal motive does not prevent the perpetrator from having a specific intention to commit genocide. By the intention, the perpetrator must have an intention to exterminate, in part or in whole, one of the four protected groups even when the goal is not achieved. Intention may include some forms: a general context that an act of crime, whether committed by same or different actors, is systematically directed to a group; the scale of the atrocities committed; the general nature of the atrocities committed in a particular territory or state; the fact that the action is intentional or systematic with the victim targeted based on membership of a particular group and does not target other groups; the existence of a doctrine or a policy that gives rise to certain acts; and the existence of repeated destructive actions directed discriminatively.

Some important indications of intention also need to be considered to categorize an action as genocide. They are: (a) the number of group members who become victims; (b) physical and proprietary targets of the group members; (c) weapons and widespread serious injuries; (d) ways of formulating plan; (e) systematic methods of killing; and ( $f$ ) experimental action to destroy a group.

\section{b. Specific Intention to Destroy in Whole or in Part}

The next mental element after the 'intention and consciousness' requires that the perpetrator has acted with a special intention to destroy a protected group in whole or in part. ${ }^{63}$ The intention to destroy a group in whole or in part as required for mental elements should be understood as a specific intention. Destruction of a group must be the original purpose of the perpetrator. The element of consciousness that the perpetrator of the genocidal crime participates in a campaign of annihilation of a group cannot substitute specific intentions but may indicate its existence. In other words, the perpetrator acts with the intention to destroy. ${ }^{64}$

Article 8 of the Indonesian Human Right Courts Law use the word menghancurkan (literally means to destroy) or memusnahkan (literally means to exterminate). The formulation of the law is different when compared to the formulation of the ICTR Statute, ICTY Statute, and Rome Statute which only use the word 'destroy'. The term 'exterminate' requires more severe proof than the term 'destroy'. The meaning of

\footnotetext{
Ibid.

Gerhard Werle, Op.cit., p. 208.

Ibid.
} 
the word menghancurkan only includes actions that cause genocide both physically and biologically. To destroy here involves physically destructive acts rather than cultural destruction. On the other hand, the meaning of the word memusnahkan is broader because it does not only cover physical and biological destruction but also cultural destruction.

Destruction or extermination in the crime of genocide may be committed against the protected group either wholly or partially. By this understanding, the crime of genocide does not include racially motivated crime only. The term 'for the purpose of destroying or exterminating a group in whole or in part' is intended as a specific intention to destroy large numbers of individuals who are members of a group. While the words 'in whole or in part' indicate that the perpetrator does not necessarily intend to destroy or to exterminate the whole group. Therefore, in this context, the perpetrator intention must be aimed at destroying or exterminating a group, in this case a separate entity and not merely individuals belonging to a particular group. Although destruction or extermination need not be directed to all members of intended group but the intention to commit destruction or extermination should be addressed to at least a substantial part of a group. ${ }^{65}$

In the verdict of the genocide case with the defendant Sikirica, the judges said that the intention to partial destruction can occur when there is evidence that the destruction was done on a significant part of a group, such as its leader. The intention is to manifest the desire to destroy a number of people chosen to have a certain impact, namely that the disappearance of these people will have an impact to the other group. An important element here is that the goal of the action is the number of people who have been chosen selectively based on specific reasons such as for their leadership in the group as a whole. ${ }^{66}$

The same thing can be found in the genocide case with defendant Jelisić. The judges interpreted the meaning of 'some members of the group' by saying that the intention in genocide can be manifested in two forms. First, the intention to destroy a large number of group members, and the act is intended to destroy the group en masse. Second, it can be a deliberate destruction of a small number of selected persons, such as group leaders with the intention that their disappearance will disrupt group survival. This condition is called intention to accidentally destroy a small number of selected people, such as group leaders, with the intention that their disappearance will affect the group's survival. This condition is called the intention to destroy the group selectively (destroying some members of the group). ${ }^{67}$

It can be concluded that the destruction or extermination occurring in a genocidal crime does not have to be directed to all members of a group. The intention can be addressed to at least a substantial part of the group. In this case, genocide does not imply the destruction or extermination of all members of a group. A crime of

65 Eddie Riyadi and Aida Milasari, Genosida, Kejahatan Perang dan Kejahatan terhadap Kemanusiaan, $1^{\text {st }}$ printing, Jakarta: ELSAM, 2007, p. 93.

66 Ibid.

67 lbid. 
genocide is realized when an act to enter into a crime of genocide is committed with specific purposes to destroy all or part of a protected group. A person can be found guilty of a genocidal act, even though the act does not cover the whole group.

\section{The Protected Group (The Group as the Object of Destructive Intention)}

An object of destruction committed by a perpetrator is a particular nation, ethnic, race, or religious group. The desire of the perpetrator here is to destroy the group (not the individual). The perpetrator must act with the intention of destroying the group 'in whole or in part'. ${ }^{68}$ It is sufficient if the perpetrator is intended to destroy an important part of a group.

The explanation of Article 8(a) of the Indonesian Human Right Courts Law states that the meaning of 'group members' is a person or some persons in the group. Meanwhile, the victim group here is a group based on nationality, ethnicity, race, and religion. The nationality group is a group of people who are deemed to have a legal attachment based on the same nationality in line with their rights and obligations on a reciprocal basis.

The ethnic group is a group whose members have language and cultural similarities or a group that identifies itself as having its own identity or a group identified by others. Race groups are usually characterized by similar physical and spiritual attributes. Special religious groups, in the context of Indonesia, are in accordance with religious religions officially recognized by the law.

Related to these protected groups, it should be noted that the special intentions characterized as genocidal crimes require the perpetrator to choose victim on the grounds that they are part of the group that is the target of destruction or extermination. The aim of the perpetrator is to destroy or to exterminate all or a part of the group, based on the membership of the individual in a particular group. The criteria for direct victimization in crimes of genocide are their membership in groups, not individual identities.

\section{G. Elements of Genocidal Crime Acts \\ 1. Killing Group Members}

The explanation of the Indonesian Human Right Courts Law does not provide a description of the acts of killing. However, based on the verdict in the Rwandan court, the killing in the context of the crime of genocide is a murder in the context of the crime of genocide. The word murder is derived from the French word meurtre, which can be interpreted as an act done with the intent to cause death. In addition, genocide is not an accidental killing or murder, as there has never been any international legal practice that categorizes an unintentional act of killing as genocide. The elements of murder in genocide do not require the existence of an element of plan, which is merely an element of intention.

68 Gerhard Werle, Op.cit., p. 209. 
Article 6(b) of the Rome Statute requires that a perpetrator of genocide may cause body and psychical injuries that are harmful, or even deadly, to certain groups. A serious body injury here is defined as a serious damage to health and a serious injury found in organs inside or outside a body. Actions that are included here, for example, are mutilation and use of force, beating with weapons, wounds caused by a machete, sexual violence, any action that causes serious body and mental injuries. ${ }^{69}$

In the Rome Statute, elements of genocide include several requirements. First, the perpetrator kills one or more persons. Second, the persons that are killed are from a particular nation, ethnic, religious. Third, the perpetrator has an intention to destroy, either in whole or in part, a particular nation, ethnic, race, or religious group. Fourth, it occurs in the context of a manifest pattern of a similar action directed towards a group or it is a measure that can inevitably result in the destruction of a particular group. ${ }^{70}$

\section{Resulting in Physical or Mental Suffering}

The Indonesian Human Right Courts Law does not explain the formulation. However, the element of this crime is that a perpetrator of genocide causes serious physical or mental injury to one or more persons. This article also does not explain the meaning of serious injury but, in general sense, it covers a circumstance that accompanies such injuries. Severe physical or mental includes physical or mental inhumane acts, inhumane or degrading treatment, rape, sexual assault, or persecution. This physical or mental suffering does not have to be permanent or incurable like rape, sexual violence, or threats while being interrogated.

In the Rome Statute, elements of physical or mental suffering include (a) the perpetrator causing serious physical or mental injury to one or more persons; (b) the injured person or persons are of a particular nation, ethnic, race, or religious group; (c) the act is intended to destroy all or part of a nation, ethnic, race, of religious group; (d) such action takes place in the context of a manifest pattern of similar action directed to that group or the action can necessarily result in the destruction of a particular group. ${ }^{71}$

\section{Causing Destructive Life Conditions}

This element covers any kinds of actions that can result in slow death of people, such as lack of proper shelter facilities, clean clothes and medicines, forced to do hard work both physically and mentally, rape, starvation, low health services to below minimum, and forced evictions. All such acts shall be intended to destroy or to exterminate all or part of group members. Thus, there are two important elements. First, the perpetrator raises certain conditions of life against one or more persons. Second, living conditions are taken into consideration to bring a destruction

Gerhard Werle, Op.cit., p. 200.

Article 6(a) of the Rome Statute.

Article 6(b) of the Rome Statute. 
or physical extermination of a group, either wholly or partially.

In the Rome Statute, elements of physical or mental suffering include: (a) the perpetrator causing serious physical or mental injury to one or more persons; (b) the injured person or persons are of a particular nation, ethnic, race, or religious group; (c) the act is intended to destroy all or part of a nation, ethnic, race, of religious group; (d) such action takes place in the context of a manifest pattern of similar action directed to that group or the action can necessarily result in the destruction of a particular group. ${ }^{72}$ For example, it can be seen in the crimes of genocide committed by Nazi against Jews in Europe. There were forced labors, forcible deportation, including ethnic cleansing. However, mass rape here is excluded but may be included if based on life conditions it can be expected to physically destroy a particular group.

\section{Imposing Measures to Prevent Birth}

The category of 'preventing birth in groups' includes sexual harassment, sterilization, forced birth control, sexual segregation, and marriage prohibition. In a patrilineal society, group membership is determined by identity of father. For example, in cases of rape, women of a group are forcibly impregnated by men from another group with the intention that the women profess to bear a child who is not from her mother's group. This action is both mental and physical. For example, rape can be an act aimed at preventing birth when women who are raped refuse to give birth. At the same time, the group can also be defeated through threats or trauma to not give birth.

Article $6(d)$ of the Rome Statute includes coercive measures aimed at the prevention of birth within a particular group. The acts include sterilization, forced birth control, marriage prohibition, and segregation of sex. Rape are also included (if it causes victim to decide not to reproduce due to trauma). However, China as the most populous country in the world that exercises birth control by force in order to undermine the number of births for reasons of social, economic, or other reasons may not be included. ${ }^{73}$

In the Rome Statute, elements of preventing birth in groups include several points. First, the perpetrator imposes certain action on one or more persons. Second, the person or persons are of a particular nation, ethnic, race, or religious group. Third, the perpetrator intends to destroy, in whole or in part, a particular nation, ethnic, race, or religious group. Fourth, the forced action is intended to prevent births within a group. Fifth, takes place in the context of a manifest pattern of similar action directed to that group or the action can necessarily result in the destruction of a particular group. ${ }^{74}$

Article 6(c) of the Rome Statute.

Gerhard Werle, Op.cit., p. 202.

Article 6(d) of the Rome Statute. 


\section{Forcible Transferring Children}

The act is not only directed to a physical displacement but also to the act of providing threats or creating trauma which then leads to the forcible transfer of children from one group to another. In addition, force here is done by using violence or threat of violence.

Article 6(e) of the Rome Statute includes the forcible transfer of children from one group to another. The act of forcible transfer is done with a special intention to destroy a group existence. When the transfer is done, children cannot grow as a part of their group or become isolated from their cultural identity. Languages, traditions, and cultures of their group became unfamiliar to the children. This act can therefore jeopardize social existence of a group, and it can harm biological existence of a group, since they are generally unable to produce offspring in their group. ${ }^{75}$

Children in this definition covers all children under 18 years old. The transfer of children is forced. This force may be physical or psychological in nature as set forth in Article 6(e) of the Rome Statute, such as the fear of violence, detention, coercion, psychological repression, or the abuse of power over certain persons or others or by taking advantage of a coercive environment. The elements of forcible transfer of children are that (a) the perpetrator forcibly transfers one or more children; (b) the transfer is from a group to another group; (c) the displaced persons are persons under 18 years old; and (d) the perpetrator knows or should know that the person or persons are under 18 years old.

Elements of forcible transfer of children include the following: ${ }^{76}$ (1) The perpetrators forcibly transferring one or more persons; (2) The person or persons are of a particular nation, ethnic, race, or religious group; (3) The perpetrator does intend to destroy, in whole or in part, the nation, group, ethnic, race, or religious group; (4) The transfer is from a group to another group; (5) The displaced persons are those under 18 years old; (6) The perpetrator knows or should have known that the person or persons are under 18 years old; (7) It occurs in the context of a manifest pattern of similar acts directed against a group or the act can inevitably result in the destruction of a particular group.

\section{H. Conclusion}

From the above description, this paper concludes some important things related to the problems of genocide and ethnic conflict of Rohingya. They are, among others, as follows:

1. Genocide is one of most serious types of international crimes. It equals to war crimes, crimes against humanity, and aggression committed by widespread and systematic killings perpetrated by state actors against a nation, an ethnic, a race, or a religious group with the ultimate aim of exterminating whole or a part of a nation, an ethnic, a race, or a religious group.

\footnotetext{
5 Gerhard Werle, Op.cit., p. 203.
}

76 Article 6(e) of the Rome Statute. 
2. Genocide, other than as a serious form of international crime, is also a form of violation of human rights on a large scale because it is carried out as a deliberate and systematic action by mass killing of a population that has been identified by perpetrators on the basis of race, culture, ethnicity, religion, and political affiliations. This is contrary to the principles of the Universal Declaration of Human Rights which respect and acknowledge each individual without discriminating the backgrounds of race, religion, political views, gender, and origin in which the right to life is the most fundamental and inherent right of human that should not be diminished under any circumstances.

3. Genocide, as a serious international crime, has been regulated in international laws through the Nuremberg Statute, the ICTR Statute, the ICTY Statute, and the Rome Statute. It has also been regulated in Indonesian national law, to be precise in Indonesian Human Right Courts Law. With the regulation of genocide as a serious international crime, then the judicial efforts against crimes of genocide can be done through international judicial system and the national judicial system.

\section{References}

\section{Books}

Arie Siswanto, Yurisdiksi Material Mahkamah Kejahatan Internasional, Ghalia Indonesia, Bogor, 2005.

Brown, Michael E., Ethnic and Internal Conflicts: Causes and Implication, Princeton University Press, Princeton, 2001.

Budi Winarno, Dinamika Isu-Isu Global Kontemporer, Center of Publishing Academic Service, Yogjakarta, 2011.

Eddie Riyadi and Aida Milasari, Genosida, Kejahatan Perang dan Kejahatan terhadap Kemanusiaan, $1^{\text {st }}$ printing, ELSAM, Jakarta, 2007.

Eddy, O.S., Hiearij, Pengadilan atas Beberapa Kejahatan Serius Terhadap Hak Asasi Manusia, Erlangga, Jakarta, 2010.

Guibernau, Monsterrat and John Rex, The Ethniciy Reader, Nationalism, Multiculturalism and Migration, Polity Press, Cambridge, 1997.

Jones, Adam, Genocide A Comprehensive Introduction, $2^{\text {nd }}$ edition, Routledge, New York, 2006.

Mahrus Ali and Syarif Nurhidayat, Penyelesaian Pelanggaran HAM Berat: In Court System \& Out Court System, Gramata Publishing, Depok, 2011.

Quigley, John, The Genocide Convention: An International Law Analysis, Ashgate Publishing Limited, Hampshire, 2006.

Schabas, William A., Genocide in International Law, Cambridge University Press, Cambridge, 2000.

Werle, Geerhard, Principles of International Criminal Law, T.M.C. Asser Press, UK, 2005. 


\section{Other Documents}

Amnesty International, "Myanmar: Military land grab as security forces build bases on torched Rohingya villages", https://www.amnesty.org/en/latest/ news/2018/03/myanmar-military-land-grab-as-security-forces-build-bases-ontorched-rohingya-villages/, accessed on March 2018.

\section{Legal Documents}

Charter of the International Military Tribunal of Nuremberg 1945.

Convention on the Prevention and Punishment of the Crime of Genocide 1948.

Universal Declaration of Human Rights 1948.

Rome Statute of the International Criminal Court 1998.

Statute of the International Criminal Tribunal for the former Yugoslavia, adopted by United Nations Security Council Resolution 827, 1993.

Statute of the International Criminal Tribunal for the Prosecution of Persons Responsible for Genocide and Other Serious Violations of International Humanitarian Law Committed in the Territory of Rwanda and Rwandan Citizens Responsible for Genocide and Other such Violations Committed in the Territory. of Neighboring States, between January 1, 1994 and December 31, 1994, adopted by United Nations Security Council Resolution 955, 1994.

Law Number 26 of 2000 on the Indonesian Court of Human Rights.

United Nations General Assembly Resolution Number 96 (I) of 1946. 